\title{
INTEGRATING INDIGENOUS SOCIO-CULTURAL FORMS IN ENVIRONMENTAL ADULT EDUCATION FOR CONFLICT RESOLUTION BETWEEN PASTORAL NOMADS AND HOST COMMUNITIES IN NIGERIA
}

\author{
Ezeala J. I. ${ }^{\square}$, Dr. Mbalisi Onyeka Festus 2 (iD \\ 1, 2 Department of Adult and Non-Formal Education, University of Port Harcourt, Nigeria
}

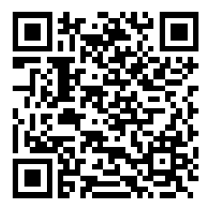

DOI: https://doi.org/10.29121/granthaalayah.v9.i2.2021.3381

Article Type: Research Article

Article Citation: Ezeala J. I., and Dr. Mbalisi Onyeka Festus. (2021).

INTEGRATING INDIGENOUS SOCIO-

CULTURAL FORMS IN

ENVIRONMENTAL ADULT

EDUCATION FOR CONFLICT

RESOLUTION BETWEEN PASTORAL

NOMADS AND HOST COMMUNITIES

IN NIGERIA. International Journal of

Research -GRANTHAALAYAH, 9(2),

345-353.

https://doi.org/10.29121/granthaa

layah.v9.i2.2021.3381

Received Date: 01 February 2021

Accepted Date: 28 February 2021

Keywords:

Indigenous Socio-Cultural Forms

Environmental Adult Education

Conflict Resolution

Pastoral Nomads

Host Communities

\section{ABSTRACT}

Conflict between pastoral nomads and host communities in Nigeria today have resulted in the degradation of the environment, and the impoverishment of the host communities. This has occasioned banditry, criminality and even armed insurgency by nomads and host communities. Strategies identified by government and researchers geared towards resolving the conflict and ensuring peaceful co-existence between farmers and herders have not helped to a large extent. Such strategies include among others, establishment of cattle colony in the federating states, establishment of the Commissions of Enquiry, and deployment of securities, environmental dialogue, environmental communication, environmental mediation, regular environmental sensitization meetings. In spite of the above-mentioned strategies, the conflict still persisted. This paper explored some of the indigenous socio-cultural forms which can be integrated in environmental adult education for forestalling conflict between pastoral nomads and their host communities in Nigeria. The paper concludes that since environmental adult education thrives on the experience of the participants derivable from their value systems which brings to bear in learning, efforts should be made to utilize these sociocultural forms which embody peoples' values systems in mobilizing and educating herders and farmers on the need for peaceful co-existence.

\section{INTRODUCTION}

Pastoral nomads and host communities' conflict in Nigeria has become a major problem that destabilizes the socio-economic life of the people resulting in the destruction of lives and property. Nomads are a group of people who engage in the rearing of animals for economic benefits. It is a form of occupation that is characterized by animal husbandry without a defined estate; farm or ranch but rely heavily on the gift of nature by following the seasonal growth of animals fed in the wild. Consequently, they migrate from one geographical location where topography differ from grassland to the shrub lands within the various geographical zones in Nigeria. This practice maybe seen to be primitive in nature considering the modern agrarian systems which are carried out in large farms covering

(C) 2021 The Author(s). This is an open access article distributed under the terms of the Creative Commons Attribution License, which permits unrestricted use, distribution, and reproduction in any medium, provided the original author and source are credited. 
Integrating Indigenous Socio-Cultural Forms in Environmental Adult Education for Conflict Resolution Between Pastoral Nomads and Host Communities in Nigeria

various hectares of land as is noticeable in Obudu Cattle Ranch of Cross Rivers State, Plateau Ranch in Plateau State, Yankari Game Reserve in Bauchi and so on.

Historically, the Fulani in the $20^{\text {th }}$ Century started migrating from the northern part of Africa into West Africa on religious conquest. This brought their cultural aspect of life into Northern Nigeria and continued the migration towards the grassland of middle belt of Nigeria. In supporting this view, Bello (2016) and Ikezue and Ezeah (2017) posit that conflict between pastoral nomads and host communities has existed for a very long time and has now assumed dangerous dimensions tending towards criminality. This criminality has its attendant monumental loss of lives and property. In modern Nigeria, some Fulani herders migrated to Middle Belt grassland and settled in the whole zones that were previously inaccessible to them. This brought them into direct contact with previously unknown cultures. Pastoral nomads believed that Allah has given them vast grassland to graze their cattle which in contrast to the cultural values of their host communities (Njoku, et al, 2016). The Middle Belt and South Eastern States have some reserved portion of land that is kept sacred for their gods which is inaccessible to indigenes and even strangers except the priests who are allowed to go there to offer some sacrifices. Due to cultural differences, the pastoral nomads go in there to graze cattle thereby desecrating the forest which members of the host communities believe that such a practice brings the wrath of their gods to bear on them with huge consequences such as strange epidemic and deaths, poor agricultural yield, famine, etc. This incursion on the cultural life of the host communities has affected them socially, politically and religiously. Pastoral nomads are always on the move while most of host communities in Nigeria practice subsistence farming using manual labour with little or no profit (Ezeaku and Jayeoba, 2012). The consequence of this was a rift of un-tested interactions between all parties and opening for misunderstandings and conflict.

In 1989, the Federal Government established a nomadic education programme as a special education intervention programme designed for educating the nomads on the implications of their activities for national economic development, how best to engage in their activities to maximize profit without causing harm on the sedentary people (farmers). This did not douse the tension, rather it kept rising regularly. In recent times, various state governments began to enact anti-grazing law with the intention of restraining nomads from encroaching into areas farmers cultivate their crops to avoid conflicts. This law triggered more conflicts in such states. This indicates that more innovative approaches are needed to forestall herders'-farmers' crisis which is becoming endemic in Nigeria. It is against this background that this paper is written to suggest the integration of indigenous sociocultural forms in environmental adult education for resolving conflicts which ensues between herdsmen and farmers.

\section{HERDER-FARMER RELATIONSHIP IN NIGERIA}

Nomadism as a culture among the Fulanis is highly cherished as a way of life of the people that is passed from one generation to another without changing the dynamics of nomadic life, which they cherish and always ready to defend. In the process of migration from one arid zone to savannah zones or grasslands, they come in contact with farmlands owned by farmers. This intrusion into the farm lands has led to wanton destruction of farm products, crops, farm implements, farm houses, hence conflict results with loss of lives as its capital consequence. This has been considered as the major source of the problem between herders and the host communities.

The activities of pastoral nomads in their host communities constitute a problem to government officials and it involves destruction of storage facilities such as barn, traditional silos, arson, encroachment on private properties without consent of their owners, poisoning the water sources often causing epidemic, raping of women in the host communities, disruption of farming seasons that may result in economic waste and famine. These certainly affect the standard of living of the host communities as well as the pastoral nomads. The host communities in an attempt to protect their common resources have been involved in repeated clashes with the nomads. This usually results in reprisal attacks by the nomads on their host communities. The host community most likely plant poisonous vegetables in the farm in an attempt to prevent cattle from entering their farm lands. Farmers in anger deliberately steal and kill stray cattle in order to recover loss done by the pastoral nomads. These activities do not enhance good economic growth of the nation. To this end, Ikezue and Ezeah (2017) assert that, the recurrent attacks by the pastoral nomads on the host communities in many states have led to the destruction of lives and property, displacement of people from their ancestral homes and communities. It has equally resulted in killing of animals by host communities thereby affecting the economic wellbeing of the nomads. In Nigeria, States such as Benue, 
Nasarawa, Plateau, Kaduna, Taraba, Rivers, Imo, Abia, Katsina, Osun and Enugu have encountered at one time or the other, pastoral nomads attack on their host communities.

Taraba State government recently suspended some sections of the open grazing law in an attempt to reduce the tension in the state after the intervention of the federal government. The reason for this suspension was to guide the herders who claimed that they were not given the opportunity to make input into the law before it was passed which negates their interest. The Taraba State House of Assembly on the 22 $2^{\text {nd }}$ of February, 2018 in conjunction with the State Reconciliation Committee agreed to suspend the law. In support of this view, Nwosu (2017) argues that, most communities in the South-East Zone have threatened reprisals to alleged attacks in an attempt to protect themselves. Cases of nomads and host communities conflict have been reported in Abia, Enugu, Imo, Anambra, Delta, Ondo, Ogun, Benue, Taraba, Plateau, Edo, Ebonyi, Nasarawa and Osun States of Nigeria. The activities of pastoral nomads prompted Yakubu Dogara, the Speaker of the $8^{\text {th }}$ House of Representatives in Nigeria to lament and criticize the killings in various parts of the country. He stated that, "Nigeria was now being painted red with blood following the killings of scores of persons, including women and children" (Yakubu, 2018:3). The reason for this lamentation was due to the fact that the Plateau State Governor - Simeon Lalong in one of their meetings, disclosed that "over 14,000 persons had been killed in Plateau and Benue States in the last few years by suspected pastoral nomads (Yakubu, 2018:4).

The causes of conflict between pastoral nomads and host communities as observed by some policy analysts may include issues of land tenure system, management of water resources, grazing area, political control of land, government policy on land usage, illiteracy, lack of facilities, quality and lack of access to extension officers, stealing or cattle rustling, destruction of crops, vandalization of farmers' stores. In the same vein, Ofuoku and Isife (2009) added that contamination of stream by cattle, disregard for local authorities, female harassment, harassment of nomads by host communities' youths, indiscriminate bush burning and defecation of cattle on roads are the causes of conflict between pastoral nomads and host communities.

\section{ENVIRONMENTAL ADULT EDUCATION}

Environmental adult education is a concept derived from a combination of two component concepts, 'adult education' and 'environmental education'. Adult education according to UNESCO 2015 Recommendation on Adult Learning and Education:

.....denotes the entire body of learning processes, formal, non-formal and informal, whereby those regarded as adults by the society in which they live, develop and enrich their capabilities for living and working, both in their own interests and those of their communities, organizations and societies (p6).

It encompasses all formal, non-formal and informal or incidental learning and continuing education (both general and vocational, and both theoretical and practical) undertaken by adults (UNESCO 2016). Adult education according to UNESCO 2015 Recommendation on Adult Learning and Education is designed for addressing issues emerging in the $21^{\text {st }}$ century, among which are environmental issues. Adult education is seen by Mbalisi and Offor (2018) as a two-pronged device with one edge pointing as an academic discipline and the other pointing as a practical human activity. As an academic discipline, adult education has its philosophies, theories, purpose, goals, objectives, principles, methods of delivery, concepts and terminologies, and as a practical human activity adult education has a set of programmes through which educators and learners achieve some practical objectives. To this effect, adult education has a goal among others, of promoting personal and professional development, thereby supporting more active engagement by adults with their societies, communities and environments. If this goal is to be realized, educating adults on environmental issues through the platform of adult education is of paramount significance. This idea is enshrined in Principle 19 of the Report of the United Nations Conference on the Human Environment which states that:

Education in environmental matters, for the younger generation as well as adults, giving due consideration to the underprivileged, is essential in order to broaden the basis for an enlightened opinion and responsible conduct by individuals, enterprises and communities in protecting and improving the environment in its full human dimension (United Nations, 1972 p.5).

This call underscores the importance of environmental education in ensuring effective practices geared towards environmental protection and the protection of natural heritage of indigenous peoples. Education in environmental matters or environmental education according to Stapp, et al (1969:34) is "education aimed at producing a citizenry 
Integrating Indigenous Socio-Cultural Forms in Environmental Adult Education for Conflict Resolution Between Pastoral Nomads and Host Communities in Nigeria

that is knowledgeable concerning the biophysical environment and its associated problems, aware of how to help solve the problems and motivated to work toward their solutions." The goal of environmental education according to UNESCO (1977) is:

To aid citizens in becoming environmentally knowledgeable and above all, skilled and dedicated human beings, willing to work individually and collectively toward achieving and maintaining a dynamic equilibrium between quality of life and quality of the environment.

The two concepts "adult education" and "environmental education" gave rise to the concept of environmental adult education which according to Sumner (2003) in Haugen (2009:1) as "a hybrid outgrowth of the environmental movement and adult education, combining an ecological orientation with a learning paradigm to provide a vigorous educational approach to environmental concern." Eheazu $(2013 ; 2016 \mathrm{~b})$ suggest that environmental adult education could be rightly seen as a product of the blend of the principles and goals of environmental education with those of adult education. He went further to define environmental adult education as the process of developing in adults (by whatever criteria they are identified), certain attitudes, skills and knowledge that will enable them to successfully interact and live in harmony with the forces and elements that surround them, as they engage in their daily activities for survival.

Environmental adult education according to Clover (2003) adds another critical lens, an ecological lens through which we can address environmental problems and give voice to the needs of those who are most affected. Environmental education according to Mbalisi (2016) is vested with the responsibility of educating adults (whose activities degrade the environment) about the environment through the application of the theories, principles, methods, approaches and programmes of adult education with the conscious intention of developing in them knowledge, attitudes and skills required to generate a sense of responsibility and commitment towards resolving present environmental problems and preventing future ones. This view corroborates Walter's (2009) view which affirms that "the field (environmental adult education) is well positioned to lead the way forward in fostering environmental awareness and action among adults, social institutions and social movements." Environmental adult education is a consciously organized environmental education for adults mostly outside the formal school system. Slattery (2000) sees it as an applied education within the context of adult education to enable significant players (who are mostly adults) in communities, groups and organizations organize and possess the necessary awareness upon which they take basic political action and to influence and educate others. It can also be seen as a process in which adult individuals gain awareness of their environment and acquire the knowledge, values, skills, experience and determination which will enable them to act individually and collectively to solve present and future environmental problems as to meet their needs without compromising those of future generations.

Adults are central in the definition of environmental adult education because they constitute the largest group of humans who impact on the environment through their socio-economic activities such as farming, use of fossil fuels for transportation, and so on which could bring about the tremendous anthropogenic environmental degradation phenomena like deforestation, dis-equilibration of the ecosystem, environmental pollution and so on (Eheazu (2016a; Mbalisi, 2016). According to Harbison (1973) and Todaro (1977) in Nzeneri (2005:26):

Adults constitute the ultimate basis for the wealth of nations. Capital and natural resources are passive factors of production; adults are the active agents who accumulate capital, exploit natural resources, build social, economic and political organizations, and carry forward national development.

The above facts, obviously, underscore the need for special education for adult population in order to ensure sustainable use of earth's resources, owing to the fact that methods and principles of adult learning (andragogy) differ from pedagogical principles. This special type of education for adult with bearing on the environment is conceptualized as environmental adult education.

\section{INDIGENOUS SOCIOCULTURAL FORMS FOR CURBING CONFLICT}

Government strategies for curbing conflict between pastoral nomads and host communities include: establishment of cattle colony in each of the States, establishment of Commissions of Inquiry, deployment of security, establishment of Grazing Reserves in each of the Federation in Nigeria which was not properly implemented. Nigeria has a total of 417 grazing reserves out of which only 113 have been gazetted and the 304 remaining are yet to be accounted for (Ibrahim, 2017 and 2018; Onanuga, 2018; Kupoluyi, 2018; Akomolafe, 2015). The reason these strategies failed was as a result of not involving the community people (grassroots) in the planning and 
implementation process toward crisis or conflict resolution. Ibrahim (2018) is of the opinion that failure of these strategies was as a result of not imbibing a holistic approach which should include a meeting of all stakeholders to solve the crisis between nomads and host communities.

Environmental adult education strategies such as environmental dialogue and environmental communication as identified in Ezeala $(2018,2019)$ are seen to be useful for curbing conflict between pastoral nomads and host communities. Planning regular meetings of spokes persons for various interests to share matters of concern to interest groups with public officials and with each other is equally a strategy for curbing conflict between pastoral nomads and host communities (Awofadeju, et al, 2015). Madu and Ewelum (2014) affirm that sensitization is an adult education strategy used for conflict resolution. Olaoba $(2001,2005)$ in Ajayi and Buhari (2014) sees mediation as a method of conflict resolution that had been so critical to African societies. However, the above-mentioned environmental adult education strategies cannot be effectively implemented without the identification of indigenous socio-cultural forms into which they can be integrated for forestalling or resolving conflicts.

Host community dwellers and pastoral nomads in Nigeria have their different traditions and receptiveness to innovation in occupational practices. Accordingly, it is necessary to consider the positive relationship between indigenous culture and receptiveness of the above- mentioned strategies among various groups of rural dwellers. Eheazu (1986) in Eheazu and Akpabio (2013) is of the opinion that cultural resistance or resilience may occur in a situation where development agents attempt to replace or supplement existing traditional institutional services with new ones by treating the previous as non-existent.

The following indigenous socio-cultural forms according to Eheazu (1986) in Ezimah (2004); Eheazu (1986) in Eheazu and Akpabio (2013) are relevant and therefore discussed below.

Traditional Leadership: The successful implementation of environmental adult education strategies begins with the recognition of the traditional head. In every community, there are traditional leaders whose roles are crucial in the delivery of any new form of development programmes which affect the traditional patterns of life of the people. Cultural resistance may infringe on the smooth implementation and delivery of environmental sustainability programmes. When development agents attempt to replace or supplement existing traditional institutional services with new ones by treating the previous services as non-existence, cultural resilience may occur (Eheazu and Akpabio, 2013).

In Nigeria, traditional rulers bear different names depending on the tribe and ethnic groups. For instance, the Igbo communities have 'Eze' or 'Igwe' as the traditional head; the Yoruba communities have 'Oba' as the traditional head; and the Hausa communities have 'Emir' as the traditional head respectively. Traditional rulers are well respected by their subjects in every Nigerian society because of their influence, personality and belief. During conflicts between pastoral nomads and host communities, traditional leadership has a role to play by organizing peace-making meetings when matters get out of hand. This has to be an informal type of meeting that is void of protocol. Rukuni, et al (2015) discovered that generally, people in rural communities acknowledge the important roles played by traditional leaders in conflict resolution. The roles of the South-East Zonal Chairman of Miyetti Allah Cattle Breeders Association are to:

1) identify the influx and outflow of cattle around the South-Eastern States in Nigeria;

2) foster peace between the locals and herders in Nigeria;

3) harmonize between the members if need arises;

4) engage the government, communities and herders for the need to have peaceful co-existence;

5) organizing committees in each of the South-Eastern States to handle peace and security matters between them and their host. For instance, in Enugu State, they have Enugu State Peace and Security Committee. In Anambra State, they have Anambra Cattle and Farmers Menace Resolution Committee and so on.

Indigenous Communication Systems: Indigenous communities of the world have in one way or the other devised their own means of communication in the absence of modern communication facilities. This indigenous communication system includes use of warning and information media such as gongs, town criers, drums and ballad singers. In some communities, masquerade group is known and feared for its practice of exposing deviants and for issuing timely warnings of impending dangers and calamities. Under tree shed, market squares, village church/mosques, village council hall and compounds serve as venues for social interaction and exchange of information in some communities. The adaptation of the indigenous communication systems by the change agents in the implementation of developmental programmes yields positive results. Religious institutions such as church for the Christians and mosque for the Muslims can serve as avenues for disseminating information that will help to 
Integrating Indigenous Socio-Cultural Forms in Environmental Adult Education for Conflict Resolution Between Pastoral Nomads and Host Communities in Nigeria

promote peaceful co-existence between pastoral nomads and host communities. The pastors and Imams as religious heads need to emphasize more on peace talks during fellowships and meetings with their members either in the village church or in the mosque.

Indigenous Knowledge and Belief Systems: Studies have shown that integrating indigenous knowledge and belief systems into rural development can attract local interest that will positively affect rural development progammes. Change agents need not to look down on the belief systems of the community people because it has an inestimable benefit to rural development programmes. For example, in Nigeria, the rural people believe so much in the market days and the moon-phase as an accurate calendar system for scheduling events and for determining the seasons. This belief could be utilized effectively in scheduling environmental sustainability programmes such as erosion control, reforestation and afforestation, climate change education, waste management and control, etc.

Pastoral nomads need to be conscientised on the belief system of the host communities because this is one of the things that trigger off conflict. Pastoral nomads claim that Allah has given them vast land to graze. This belief system makes them to desecrate the evil forest of their hosts without the knowledge of community heads. The 'golden rule' as stated in the Bible, Quran, and Hindu and so on says 'that which you do not want others to do to you, do not do unto others'. In Nigeria, there is freedom of movement, and that does not mean that one should undermine other peoples' right. The market days need to be taken seriously in scheduling awareness programmes and so on because, once the programme coincides with those market days, people will not turn up.

Traditional Organizational Forms: The socio-economic life of the rural people is organized within institutional groupings such as clan, self-help groups and clubs which serve as a bridge between traditional and modern political, social and economic systems. The essence of traditional institutions is to preserve the customs and traditions of the people and to manage conflict arising among or between members of the community by the instrumentality of laws and customs of the people. These traditional organizational forms can also be useful means for mobilization of people for environmental adult education programmes aimed at rural development. Rural populations among the Igbos of South-Eastern Nigeria are known for such organizational forms. The use of traditional organizations becomes necessary considering its simple organizational structure and easy mobilization process which reduces administrative and bureaucratization costs; and enhances rural development delivery systems.

Community-Based Organizations (CBOs) can be used as tools for creating awareness among the members of their group on how to maintain peace. For instance, Community-Based Organizations in Okpanku community in Aninri Local Government Area such as Nne-Amaka Women Organization, Fishermen Organization, Farmers Group and so on can include discussions that borders on maintenance of peace within and around their immediate communities. Miyetti Allah Cattle Breeders Association of Nigeria as a professional organization can as well serve as a medium to reach their members for discussions on the importance of peaceful coexistence with their host communities who are predominantly farmers.

In the course of implementing the above discussed EAE strategies for curbing conflict between the herders and farmers, it is important to integrate the above listed socio-cultural forms to enhance the management of sustainable environment. Eheazu and Akpabio, (2013) assert that there is need to elicit the co-operation of the indigenous leadership within the community to at least, give the process of stamp of indigenous authority. They went further to state that existing indigenous systems of communicating services (such as use of town criers, talking drums and ballad singers) need to be employed (especially where modern telecommunication facilities and media are absent) to assemble the target group. Obinne and Ozowa (1997) as cited in Eheazu and Akpabio (2013:424) assert that, "even where it is possible to apply the modern information communication modes, there is still the informed belief that the pace of adoption of agricultural innovations by rural illiterate farmers would be quickened if traditional and modern approaches are blended".

Some public meeting places such as market squares, church/mosque, and village council halls and under a big tree equally serve as indigenous communicating systems as well as venues for communicating information regarding the environment (Eheazu and Akpabio, 2013). Indigenous belief systems should be taken into consideration while planning rural development programmes. For example Ezimah (2004) disclosed that in Nigeria, illiterates believe in the market days and moon-phase as an accurate calendar system for scheduling events; and that the traditional calendar system should be accommodated in the scheduling of adult education programmes such as literacy classes, agricultural demonstration meetings, just to mention but few. 
Indigenous socio-cultural forms are used to reach the nomads whose activities usually trigger conflict between them and their host communities. They are reached to participate in meetings organized to dialogue on the best way to co-exist without conflict. Meetings are also organized to sensitize them on the impact of their activities on the livelihoods, emotions and traditional beliefs of their host communities. Over-grazing, pollution of air and water and destruction of crops of host community members impact negatively on them. Trespassing the sacred forests or sites of the host communities for grazing of their herds triggers anger and heightens tensions on members of the host communities because they feel that their culture is being trampled upon, hence conflict ensues. The herders should be made to understand through the indigenous forms, how their excesses with their herds subject members of their host communities to untoward poverty and hardship and thereby encouraged to refrain from such excesses to avoid conflict. On the other hand, host members of communities can be made to understand the nutrient value of dungs which they can maximize to grow their crops in order to achieve increased productivity. Nomads are to be made to understand that farmers cherish and value their crops and traditional heritage as nomads value their herds through meetings and gatherings organized through the use of indigenous socio-cultural forms.

\section{CONCLUSION}

Indigenous socio-cultural forms bring people's traditional systems to bear in an attempt to ensure effective mobilization of the people for participation in any educational and development programmes. This suggests that people react to issues that bother much on their traditional value systems. So, planning any programme (education or development), cognizance must be given to peoples' belief system in order to allay their fears of being trampled upon and suspicion of attack by other co-existing groups. This engenders understanding to co-exist which dissolves any form of suspicion between and among herders and members of host communities who are predominantly farmers. Since environmental adult education thrives on the experience of the participants derivable from their value systems which brings to bear in learning, efforts should be made to utilize these sociocultural forms which embody peoples' values systems in mobilizing and educating herders and farmers on the need for peaceful co-existence.

\section{SOURCES OF FUNDING}

This research received no specific grant from any funding agency in the public, commercial, or not-for-profit sectors.

\section{CONFLICT OF INTEREST}

The author have declared that no competing interests exist.

\section{ACKNOWLEDGMENT}

None.

\section{REFERENCES}

[1] Ajayi, A. T., and Buhari, L.O. (2014). Methods of conflict resolution in African traditional society. An International Multidisciplinary Journal, Ethiopia. 8 (2) 138-157

[2] Akomolafe, E.A (2015). Mapping and analysis of site for grazing reserves in some states of Nigeria. Published M.Sc. thesis. Amadu Bello University. Zaria.

[3] Awofadeju, P. O., Taiwo, T. F., Akinrosoye, A. J., Ewuola, P. O., and Adeagbo. S. A. (2015). Impact of mass media in conflicts resolution. International Journal of Advanced Academic Research. 1(1) $1-21$

[4] Bello, N. (2016). Enugu got security alert before attacks. The Guardian Newspaper, April 28th, pg. 5.

[5] Clover, D.E. (2003). Environmental adult education: Critique and creativity in a globalized world. New direction for Adult and Continuing Education, 99, 5-15. 
Integrating Indigenous Socio-Cultural Forms in Environmental Adult Education for Conflict Resolution Between Pastoral Nomads and Host Communities in Nigeria

[6] Eheazu, B. A. (2016a). Situational challenges of environmental degradation in Nigeria: Adult education as a response (University of Port Harcourt Valedictory Lecture series, No 6): Port Harcourt: University of Port Harcourt Press Ltd.

[7] Eheazu, B. A. (2016b). Fundamental of environmental adult education. Port Harcourt: University of Port Harcourt Press Ltd.

[8] Eheazu, B.A. (2013). Antecedents of environmental adult education. In B.A. Eheazu; C.N. Barikor; and I. S. Nzeneri (Eds). Readings in Adult and Non-Formal Education. Port Harcourt, University of Port Harcourt press. (1) 21.

[9] Eheazu, C. L. and Akpabio, J. (2013). Approaches for communicating environmental sustainability strategies to illiterate rural farmers in Nigeria. Journal of Education in Developing Areas. 21(2), 417 - 426.

[10] Ezeala, I. J., Nzeneri, I. S. and Ezimah, M. O. A. (2018). Dialogical approach to curbing conflict between pastoral nomads and host communities in Enugu State of Nigeria. Journal of Educational Studies. 3 (1), 253 - 262.

[11] Ezeala, I. J., Nzeneri, I. S., and Ezimah, M. O. A. (2019). Communication as a strategy for curbing conflict between pastoral nomads and host communities in Enugu State, Nigeria. Journal of Educational Studies. 4(1), $88-93$.

[12] Ezeaku, P. I. and Jayeoba, O. J. (2012). Spatial patterns of land use systems and the implications of Land Use Act 1978 for Agricultural Development in South-Eastern Nigeria. In H. M. Ijeomah and A. A. Aiyeloja (eds). Challenges to sustainable Production in Agriculture and Environment: Nigeria Perspectives. Lagos: Topbase Nigeria Limited, 105-129.

[13] Ezimah, M. O. A. (2004). Knowing Adult Education: Its nature, scope and processes. Imo: Springfield publishers Ltd.

[14] Haugen, C.S. (2009). Adult learners and the environment in the last century: An historical analysis of environmental adult education literature. Electronic Green Journal, 1 (29), 1-14.

[15] Ibrahim, J. (2017). The danger of boxing in the pastoralists (II). Daily Trust Newspaper. Accessed and retrieved on 07/08/2018 from https://www.daily trust.com.ng

[16] Ibrahim, J. (2018). How to resolve herdsmen crisis - Nigerian Working Group. Premium Times. Retrieved from https://www.premiumtimesng.com on 06/08/2018.

[17] Ikezue, C. E. and Ezeah, P. (2017). Recurrent conflict among migrant Fulani herdsmen and indigenous communities of Southern Nigeria: A review of literature. International Journal of Health and Social Inquiry. 3(1), 152-169.

[18] Kupoluyi, A. (20018). Ending deadly herdsmen attacks. Accessed and retrieved on 13/05/2019 from https://punchng.com/ending-deadly-herdsmen-attacks/

[19] Madu, C. O and Ewelum, J. N. (2014). Adult education strategies as sine qua non for conflict resolution in Nigeria. International Journal of Advanced Research in Science, Engineering and Technology. 1(4), $174-178$

[20] Mbalisi, O.F. (2016). Programme development in environmental adult education. In S.O. Oluwuo and J.D. Asodike (Eds.) Managing schools for productivity: Emerging perspectives, 200-231. Port Harcourt; Nigeria: Pearl Publishers International Ltd.

[21] Mbalisi, O.F. and Offor, B.O. (2018). Potentials of adult education for achieving environmental sustainability by the 2030. National Council for Adult Education Journal, 23 (1), 293-306.

[22] Njoku, L., Akutu, G., Tanba, S. and Olisa, V. (2016). Herdsmen on rampage. The Guardian Newspaper, April 29. Pg. 24, 2

[23] Nwosu, C. (2017). Between fulani herdsmen and farmers. Accessed from www.republic.com.ng/aprimary2017/fulani-herdsmen.farmers/\# on 19/01/2018

[24] Nzeneri. I. S. (2005). An introduction to research methods and statistics. Lagos, African Heritage Publishers.

[25] Ofuoku, A. U. and Isife, B. I. (2009). Causes, effects and resolution of farmers-nomadic cattle herders conflicts in Delta State, Nigeria. International Journal of Sociology and Anthropology. 1(2), 47-54.

[26] Onanuga, A. (2018). Way out of herdsmen attacks by NBA, others - The nation Nigeria. Accessed and retrieved on 07/08/2018 from https://www.thenationonlineng.net/way-herdsmen-attacks-nb

[27] Rukuni, T., Machingambi, Z., Musingafi, M. C., and Kaseke, K. E (2015). The role of traditional leadership in conflict resolution and peace building in Zimbabwean rural communities: The case of study Bikita District. Journal of Public Policy and Administration Research 5(3), 75-79 
[28] Slattery, D. (2000). Adult environmental education and ecology. Australian Journal of Environmental Education. 15(16), 85-93.

[29] Stapp, W.B; Havlick, S; Bennett, D; Bryan Jr, W; Fulton, J; MacGregor, J; Nowak, P; Swan, J; and Wall, R. (1969). The concept of environmental education. The Journal of Environmental Education, 1 (1), 30-31.

[30] UNESCO (1977). Tbilisi declaration. UNESCO.

[31] UNESCO (2015). Recommendations on Adult Learning and Education. UNESCO.

[32] UNESCO (2016). 3RD global report on adult learning and education. UNESCO.

[33] United Nations (1972). Report of the United Nations conference on the human environment. United Nations.

[34] Walter, P. (2009). Philosophies of adult environmental education. Adult Education Quarterly, 60 (1), 3-25.

[35] Yakubu, D. (2018). Nigeria being painted red with blood. Vanguard Newspaper. 17 January, pg. 1-5. 